\title{
LETTERS
}

\section{Where do matters stand with CMAJ?}

It is now nearly one year since the latest CMAJ versus the Canadian Medical Association (CMA) debacle. I and others wrote then to express concern at the successive changes in the journal, and particularly the decision to disband the Journal Oversight Committee (JOC). It seemed that those decisions arose from financial issues, not the journal's supposed "falling reputation." I felt CMAJ's international status had remained outstanding during Dr. Fletcher's tenure as editor-in-chief. I asked if the membership had been consulted before the decision was taken to fire him.

The original announcement by the CMA Board of Directors stated that a task force had been created to propose "a new mission statement" with the goal to "recast the CMAJ as a world-class leading journal." ${ }^{1}$ The announcement concluded with assurances that a new permanent editor-in-chief would soon be appointed.

Shortly afterward, an editorial signed by many of the remaining staff was published. ${ }^{2}$ Readers were told that the CMA and the new governing body were resolved to main- tain the high quality of the journal. The writers added that they "have been assured by the CMA and the CEO of NewCo, the CMA subsidiary to which CMAJ was transferred in late 2014" that complete editorial independence would follow. However, the editorial noted the credibility of such an assurance seemed doubtful, because the CMA had not provided a plausible public justification for the dismissal of the editor or the JOC.

When the next request to review a paper for CMAJ arrived, I hesitated because I felt conflicted about being asked to assist a journal that seemed unwilling to help itself. I thought other readers and reviewers would feel likewise.

Now, a year later, another editorial provides an encouraging update. ${ }^{3}$ Nevertheless, I hope I am not alone in wanting to know more about where matters now stand. In the absence of the old JOC and the creation of a new governance council, what steps have been taken to act on all the good intentions previously announced? How have relations between the CMA Board and NewCo (now Joule) evolved? Why is there not more transparency about such matters? Can CMA members recommend people to serve on the governance council? Has the board reported to members the results of the reader survey and the consultation with outside experts? What advice was given? Finally, will the board still be able to exercise sweeping house-cleaning measures with no due process and no consequences?

\section{Barry Pless CM MD DSc}

Professor Emeritus, Department of

Pediatrics and Epidemiology, McGill

University, Montréal, Que.

Editor Emeritus, Injury Prevention

Cite as: CMAJ 2017 March 20;189:E445. doi: $10.1503 / \mathrm{cmaj} .732880$

\section{References}

1. CMA Board of Directors announces restructuring and modernization plan for CMAJ [press release]. Ottawa: Canadian Medical Association; 2016 Feb. 29. Available: www.cma.ca/En/Pages/ cma-board-of-directors-announces-restructuring -and-modernization-plan-for-the-cma-journal.aspx (accessed 2017 Feb. 5)

2. Kelsall D, Patrick K, Stanbrook MB, et al. Upholding the integrity of your CMAJ. CMAJ 2016;188: E113-4.

3. Kelsall D, Flegel K, Patrick K, et al. Renewal for CMAJ. CMAJ 2017;January 9;189:E1, doi:10.1503/ cmaj.161478.

Competing interests: None declared. 